\title{
Kuantitas, Kualitas, dan Daya Fagositosis Neutrofil pada Saliva dan Darah Bayi Baru Lahir dengan Faktor Risiko Sepsis
}

\section{Quantity, Quality, and Neutrophils Phagocytosis in Saliva and Blood of New Born Babies with Sepsis Risk}

\author{
Ari Yunanto ${ }^{1}$, MS Chandra ${ }^{2}$, Edi Widjajanto ${ }^{3}$, M Aris Widodo $^{4}$ \\ ${ }^{1}$ Laboratorium IImu Kesehatan Anak Fakultas Kedokteran Universitas Lambung Mangkurat Banjarmasin \\ ${ }^{2}$ Laboratorium Ilmu Kesehatan Anak Fakultas Kedokteran Universitas Brawijaya Malang \\ ${ }^{3}$ Laboratorium Patologi Klinik Fakultas Kedokteran Universitas Brawijaya Malang \\ ${ }^{4}$ Laboratorium Farmakologi Fakultas Kedokteran Universitas Brawijaya Malang
}

\begin{abstract}
ABSTRAK
Sepsis neonatal adalah sindrom klinik pada bulan pertama kehidupan bayi akibat respons sistemik terhadap infeksi. Analisis saliva menjadi sumber daya penting untuk mengevaluasi kondisi saliva pada implikasi keadaan fisiologis dan patologis, yang berguna sebagai sarana untuk diagnosis penyakit. Neutrofil merupakan merupakan sel yang pertama kali datang di lokasi inflamasi dan merupakan komponen seluler utama untuk respon natural selama infeksi akut, influks ke saliva terjadi terus-menerus. Tujuan dari penelitian ini adalah untuk mengetahui kualitas dan kuantitas neutrofil saliva dan darah bayi baru lahir dengan risiko sepsis. Sebanyak 30 sampel dari saliva dan darah bayi dengan risiko sepsis diambil sebagai kasus serta 30 sampel saliva dan darah bayi sehat sebagai kontrol. Terdapat perbedaan yang bermakna antara jumlah neutrofil, daya fagositosis (30 menit dan 60 menit), ekspresi TLR2 \& TLR4, myeloperoksidase (MPO), H2O2, dan laktoferin (LTF) pada saliva dan darah bayi kasus dibandingkan dengan saliva dan darah bayi kontrol. Hasil menunjukkan neutrofil saliva dapat digunakan sebagai salah satu biomarker adanya sepsis neonatal awitan dini.
\end{abstract}

Kata Kunci : Fagositosis, $\mathrm{H}_{2} \mathrm{O}_{2}$, LTF, MPO, neutrofil, sepsis neonatal, TLR2, TLR4

\section{ABSTRACT}

Neonatal sepsis is a clinical syndrome of bacteriemia characterized by systemic signs and symptoms of infection in the first month of life. Saliva is an important body fluid for detecting the physiological and pathological situations of the human body. Neutrophils are considered to participate in the acute response against pathogens in many tissues, and influx into the oral cavity occurs at any time.The aim of this research was to analys quantity, quality and phagocytosis of neutrophil on saliva and blood from newborn with sepsis risk factors. Thirty samples saliva and blood were taken from newborn with sepsis risk factors who fulfilled inclussion criteria, and 30 samples saliva and blood from healthy newborn as control. There were a significant differences in means value of the salivas neutrophils quantity, phagocytosis (30 second), phagocytosis (60 second), TLR2, TLR4, MPO, $\mathrm{H}_{2} \mathrm{O}_{2}$, and LTF between the two groups $(p<0,05)$. The bloods neutrophils quantity, phagocytosis (30 second), phagocytosis (60 second), TLR2, TLR4, MPO, $\mathrm{H}_{2} \mathrm{O}_{2}$, and LTF also demonstrated significant differences between these two groups $(p<0,05)$. It can be concluded that saliva neutrophil can be used as one of biomarker tool to diagnose early-onset neonatal sepsis.

Keyword: $\mathrm{H}_{2} \mathrm{O}_{2}$,LTF, MPO, neutrophil, phagocytosis, sepsis neonatal, TLR2, TLR4

Jurnal Kedokteran Brawijaya, Vol. 27, No. 2, Agustus 2012; Korespondensi: Ari Yunanto. Laboratorium Ilmu Kesehatan Anak Fakultas Kedokteran Universitas Lambung Mangkurat Banjarmasin, Jl. Brigadir Jenderal Hasan Bisri Banjarmasin Tel. (0511) 54177 Email: ariefkaunlam@gmail.com 


\section{PENDAHULUAN}

Sepsis neonatal, yang sering disebut sepsis neonatorum atau septikemia adalah sindrom klinik pada bulan pertama kehidupan bayi akibat respons sistemik terhadap infeksi dengan ditemukannya bakteri penyebab pada biakan darah (1). Sepsis masih merupakan penyebab utama kematian neonatus khususnya di negara berkembang. Sepsis pada neonatus merupakan penyebab morbiditas dan mortalitas bermakna terutama pada bayibayi preterm dan bayi berat lahir rendah. Meskipun perkembangan unit perawatan intensif neonatus semakin pesat, namun case fatality rate (CFR) pada sepsis masih berkisar $20 \%$ sampai $50 \%$ (2).

Aktivasi sistem imun natural menghasilkan respon inflamasi yang sangat penting untuk mengendalikan infeksi secara cepat sebelum timbul gejala-gejala penyakit. Respon imun natural menggambarkan strategi untuk pertahanan penjamu terhadap berbagai agen infeksi, meliputi patogen-patogen bakteri, fungi, dan virus. Selain itu, sistem imun natural juga berkontribusi terhadap inisiasi dan mendukung respon imun adaptif. Fagosit merupakan faktor penting yang berperan dalam respon inflamasi akut karena kemampuannya untuk menelan dan merusak berbagai patogen secara efisien. Berbagai sel yang tergolong sebagai fagosit profesional meliputi neutrofil, monosit, makrofag, eosinofil, dan selsel dendrit. Pada kelompok sel ini, neutrofil merupakan sel paling melimpah dan biasanya merupakan sel yang pertama kali datang di lokasi inflamasi dan merupakan komponen seluler utama untuk respon imunitas natural selama infeksi akut (3).

Leukosit pada cairan krevikular ginggival terdiri atas $90 \%$ leukosit polimorfonuklear (PMN) dan $10 \%$ sel mononuklear (4). Pada sel mononuklear, $60 \%$ merupakan limfosit B, 20-30\% merupakan limfosit T dan 10-15\% adalah makrofag. Sekitar $80 \%$ PMN bersifat viabel dan fungsional di dalam cairan krevikuler. Sel ini mampu melakukan fagositosis dan membunuh mikroorganisme meskipun efisiensi dalam fagositosis lebih rendah dibandingkan neutrofil darah sel. PMN mungkin bersifat fungsional pada jarak dekat dari batas ginggival melalui aliran cairan ginggival sepanjang permukaan gigi, akan tetapi ketika neutrofil berada di saliva akan mengalami degenerasi melaui lisis osmotik. Lisozim dan peroksidase yang dilepaskan oleh lisosom PMN selama fagositosis mungkin berperan dalam mengatur pertumbuhan bakteri pada krevikuler gingival. Selain itu, meskipun neutrofil berpartisipasi dalam respon akut terhadap patogen di berbagai jaringan, influks menuju kavitas oral terjadi kapan saja. Influks neutrofil tersebut terjadi akibat faktor kemoatraktan yang tersedia di lingkungan oral meliputi mikroorganisme, toksin, kemokin, dan produk degradasi seluler (5).

Meskipun pemanfaatan marker biologis dan pengembangan penelitian saliva untuk penegakan diagnosis penyakit tertentu pada orang dewasa sudah banyak dilakukan, tetapi sampai saat ini belum pernah dilaporkan hasil penelitian tentang peranan saliva pada sepsis neonatal. Penelitian dilakukan pada saliva pada bayi dengan risiko sepsis, untuk melihat korelasi (kuantitas jumlah neutrofil dan jumlah Toll Like Receptor2
(TLR2), Toll Like Receptor4 (TLR4) teraktivasi dan kualitas (produksi Myeloperoxidase (MPO), $\mathrm{H}_{2} \mathrm{O}_{2}$, Lactoferrin (LTF), daya fagositosis neutrofil, yang dapat digunakan sebagai petanda awal adanya sepsis neonatorum.

\section{METODE}

Penelitian ini telah mendapatkan pengesahan penelitian dari Komite Etik. Sebanyak 30 sampel saliva dan darah diambil dari bayi baru lahir dengan faktor risiko yang memenuhi kriteria inklusi dan 30 sampel saliva dan darah bayi baru lahir tanpa faktor risiko sebagai kontrol, dari orang tua yang telah menandatangani informed consent, sehingga jumlah sampel saliva dan darah sebanyak 60 sampel uji. Penelitian dilakukan pada bulan Juli $\mathrm{s} / \mathrm{d}$ Desember 2011, di Divisi Neonatologi SMF/Bagian Ilmu Kesehatan Anak Rumah Sakit Umum Daerah Ulin/Fakultas Kedokteran Universitas Lambung Mangkurat Banjarmasin, pemeriksaan laboratorium di Laboratorium Biomedik Fakultas Kedokteran Universitas Brawijaya Malang.

Biomarker yang diukur pada penelitian ini meliputi daya fagositosis dengan menggunakan metode pengukuran in vitro; $\mathrm{H}_{2} \mathrm{O}_{2}$, LTF, dan MPO dengan menggunakan metode pengukuran kolorimetri; serta neutrofil, TLR2, dan TLR4 dengan menggunakan metode pengukuran flow cytometry.

Kriteria inklusi meliputi bayi baru lahir dengan risiko sepsis neonatal, lahir dari ibu yang memenuhi kriteria 1 risiko mayor atau 2 risiko minor (6). Risiko mayor meliputi ketuban pecah $>24$ jam; saat intrapartum suhu $>38^{\circ} \mathrm{C}$; korioamnionitis; denyut jantung janin menetap $>160$ $\mathrm{x} /$ menit; ketuban berbau. Risiko minor meliputi ketuban pecah $>12$ jam; saat inpartu suhu $>37,5^{\circ} \mathrm{C}$; nilai apgar rendah (menit ke- $1<5$, menit ke- $<<7$ ); bayi berat lahir sangat rendah (BBLSR) <1,500 gram; usia gestasi <37 minggu; kehamilan ganda; keputihan pada ibu yang tidak diobati; ibu dengan infeksi saluran kemih (ISK)/tersangka ISK yang tidak diobati. Kriteria eksklusi yang digunakan lahir di luar RSUD Ulin; kelainan bawaan yang berat; asfiksia berat; berat lahir amat sangat rendah $(<1000$ gram).

\section{HASIL}

Perbedaan Jumlah Neutrofil , Ekspresi TLR2 dan TLR4 serta Daya Fagositosis pada Saliva Bayi dengan Risiko Sepsis dan Normal

Pada Tabel 1 terlihat rerata jumlah neutrofil pada saliva antara bayi normal $(5,63 \pm 6,78 \%)$ lebih rendah secara bermakna $(p=0,02)$ dibandingkan dengan bayi dengan sepsis $(14,43 \pm 12,21 \%)$. Kadar TLR2 pada saliva antara bayi normal $(40,06 \pm 23,6 \%)$ juga lebih rendah secara bermakna $(p=0,011)$ bila dibandingkan dengan bayi dengan sepsis $(64,97 \pm 26,42 \%)$. Terlihat pula rerata TLR4 pada saliva bayi normal $(0,57 \pm 0,53 \%)$ yang lebih rendah dibandingkan bayi dengan sepsis $(1,5 \pm 1,61)$. Rerata TLR2-TLR4 pada saliva bayi normal $(8,69 \pm 7,06 \%)$ juga lebih rendah dibandingkan bayi dengan sepsis $(23,02 \pm 22,46 \%)$. Terlihat juga adanya perbedaan yang sangat bermakna $(p=0,000)$ rerata jumlah neutrofil pada saliva antara bayi normal $(44,75 \pm 6,76)$ dengan bayi dengan sepsis $(81,72 \pm 6,77)$. Rerata fagositosis (pengamatan 30 menit) pada saliva 
antara bayi normal $(33,97 \pm 9,34)$ dengan bayi dengan sepsis $(49,55 \pm 7,69)$ menunjukkan ada perbedaan yang sangat bermakna $(p=0,000)$. Pada pengamatan 60 menit juga menunjukka rerata fagositosis pada saliva bayi normal $(65,27 \pm 7,70)$ lebih rendah dibandingkan dengan bayi dengan sepsis $(75,64 \pm 6,53)$. Hal ini menunjukkan secara keseluruhan kuantitas dan daya fagositosis netrofil yang diperiksa melalui saliva pada bayi dengan risiko sepsis neonatal lebih tinggi secara bermakna dibandingkan bayi normal.

Tabel 1. Perbandingan jumlah neutrofil, ekspresi TLR2 dan TLR4 serta daya fagositosis pada saliva bayi dengan risiko sepsis dan normal

\begin{tabular}{lccc}
\hline \multirow{2}{*}{ Variabel } & Bayi normal & Bayi dengan sepsis & \multirow{2}{*}{$p$-value } \\
\cline { 2 - 3 } & Rerata \pm SD (\%) & Rerata \pm SD (\%) & \\
\cline { 1 - 2 } Jumlah neutrofil & $5,63 \pm 6,78$ & $14,43 \pm 12,21$ & 0,021 \\
dibanding TLR2 dan TLR4 & $40,06 \pm 23,6$ & $64,97 \pm 26,42$ & 0,011 \\
TLR2 & $0,57 \pm 0,53$ & $1,5 \pm 1,61$ & 0,044 \\
TLR4 & $8,69 \pm 7,06$ & $23,02 \pm 22,46$ & 0,026 \\
TLR2-TLR4 & $44,75 \pm 6,76$ & $81,72 \pm 6,77$ & 0,000 \\
Jumlah neutrofil & $33,97 \pm 9,34$ & $49,55 \pm 7,69$ & 0,000 \\
dibanding fagositosis & $65,27 \pm 7,70$ & $75,64 \pm 6,53$ & 0,000 \\
Fagositosis (30 menit) & Fagositosis (60 \pm menit) & & \\
\hline
\end{tabular}

Perbedaan Jumlah Neutrofil dan Ekspresi TLR2 dan TLR4 serta Daya Fagositosis pada Darah Bayi dengan Risiko Sepsis dan Normal

Gambaran kuantitas dan daya fagositosis neutrofil yang lebih tinggi secara bermakna pada bayi dengan risiko sepsis dibandingkan bayi normal juga didapatkan pada sampel darah. Tabel 2 menunjukkan bahwa rerata jumlah neutrofil pada darah bayi normal $(0,21 \pm 0,09 \%)$ lebih rendah dibandingkan dengan bayi sepsis $(1,09 \pm 0,61 \%)$. Demikian pula rerata TLR2 pada darah antara bayi normal $(81,74 \pm 11,79 \%)$ lebih rendah dibandingkan dengan bayi dengan sepsis $(92,51 \pm 5,51 \%)$ menunjukkan ada perbedaan yang sangat bermakna $(p=0,003)$. Perbedaan yang bermakna $(p=0,000)$ juga didapatkan pada rerata TLR4 pada darah bayi normal $(0,12 \pm 0,06 \%)$ dibandingkan bayi dengan sepsis $(1,42 \pm 0,71 \%)$. Rerata TLR2-TLR4 pada darah bayi normal $(2,85 \pm 2,08 \%)$ juga lebih rendah dibandingkan bayi dengan sepsis $(7,17 \pm 5,06 \%)$. Perbedaan yang bermakna $(p=0,000)$ juga ditemukan pada rerata jumlah neutrofil darah bayi normal $(19,28 \pm 13,26)$ dengan bayi dengan sepsis $(56,14 \pm 5,27)$. Demikian pula pada rerata fagositosis (pengamatan 30 menit) pada darah antara bayi normal $(23,61 \pm 11,24)$ dengan bayi dengan sepsis $(39,04 \pm 7,49)$ menunjukkan ada perbedaan yang sangat bermakna $(p=0,000)$. Terdapat perbedaan yang sangat bermakna $(p=0,000)$ rerata daya fagositosis (pengamatan 60 menit) pada darah antara bayi normal $(46,13 \pm 17,63)$ dengan bayi dengan sepsis $(72,84 \pm 8,02)$. Rerata fagositosis pengamatan 30 menit bayi dengan sepsis $(49,55 \pm 7,69)$ bila dibandingkan dengan pengamatan 60 menit tetap pada bayi dengan sepsis $(75,64 \pm 6,53)$ menunjukkan ada perbedaan yang sangat bermakana pula $(p=0,000)$. Hal ini menjelaskan bahwa pada darah pasien sepsis neonatal menunjukkan peningkatan fagositosis dibandingkan pada pasien normal pada pengamatan 30 dan 60 menit.
Tabel 2. Perbandingan jumlah neutrofil dan ekspresi TLR2 dan TLR4 serta daya fagositosis pada darah bayi dengan risiko sepsis dan normal

\begin{tabular}{lccc}
\hline \multicolumn{1}{c}{ Variabel } & Bayi normal & Bayi dengan sepsis & \multirow{2}{*}{$p$-value } \\
\cline { 2 - 3 } & Rerata $\pm \mathrm{SD}(\%)$ & Rerata $\pm \mathrm{SD}(\%)$ & \\
\cline { 1 - 2 } Jumlah Neutrofil & $0,21 \pm 0,09$ & $1,09 \pm 0,61$ & 0,000 \\
dibanding TLR 2 dan TLR4 & & & \\
& & & 0,003 \\
TLR2 & $81,74 \pm 11,79$ & $92,51 \pm 5,51$ & 0,000 \\
TLR4 & $0,12 \pm 0,06$ & $1,42 \pm 0,71$ & 0,000 \\
TLR2-TLR4 & $2,85 \pm 2,08$ & $7,17 \pm 5,06$ & 0,005 \\
Jumlah Neutrofil & $19,28 \pm 13,26$ & $56,14 \pm 5,27$ & 0,000 \\
dibanding daya fagositosis & $23,61 \pm 11,24$ & $39,04 \pm 7,49^{\mathrm{a}}$ & 0,000 \\
Fagositosis (30 menit) & $46,13 \pm 17,63$ & $72,84 \pm 8,02^{\mathrm{b}}$ & 0,000 \\
Fagositosis (60 \pm menit) & & & \\
\hline
\end{tabular}

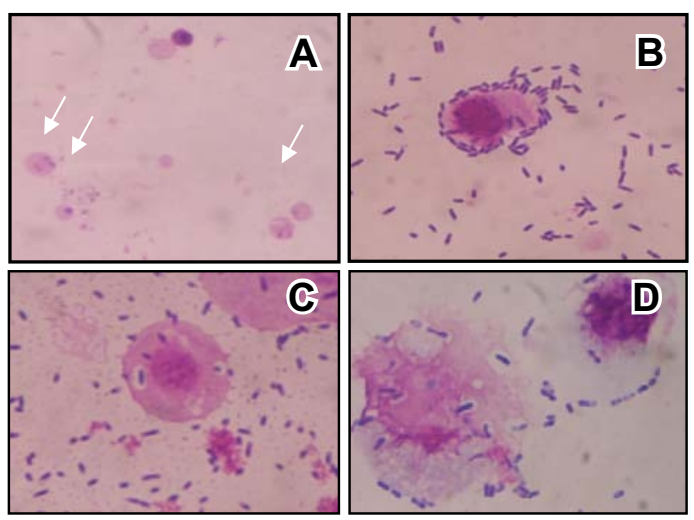

Gambar 1. Neutrofil dan proses adhesi dan fagositosis bakteri pada saliva dengan mikroskop pembesaran $1000 \mathrm{x}$

Keterangan: (A). neutrofil (tanda panah) tanpa pemaparan bakteri, (B) dan (C). neutrofil dengan pemaparan bakteri 30 menit, (D) neutrofil dengan pemaparan bakteri 60 menit.

Pada Gambar 1 menunjukkan adanya aktifitas neutrofil yang diambil dari sampel saliva. Pada kontrol tidak terdapat aktivitas fagositosis karena tidak ada paparan bakteri, sedangkan pada paparan bakteri terlihat adanya proses adhesi dan fagositosis. Pada hasil Scanning Electron Microscope (SEM) di Gambar 2 jelas terlihat bakteri di dalam fagosom neutrofil.

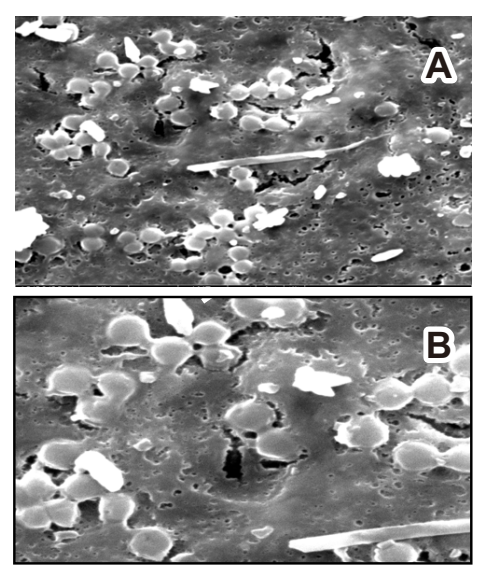

Gambar 2. Neutrofil saliva dengan pemaparan bakteri pada SEM;

Keterangan: (A) pada mikroskop dengan pembesaran 20.000 x, (B). pada mikroskop dengan pembesaran $40.000 \mathrm{x}$. Anak panah mennunjukkan bakteri di dalam fagosom. 
Perbedaan Kadar MPO, $\mathrm{H}_{2} \mathrm{O}_{2}$, dan LTF pada Saliva Bayi dengan Risiko Sepsis dan Normal

Tabel 3 menunjukkan bahwa ada perbedaan yang sangat bermakna $(p=0,000)$ mean kadar MPO pada saliva antara bayi normal $(38,74 \pm 10,57)$ dengan bayi dengan sepsis $(75,23 \pm 13,18)$. Demikian pula pada mean kadar $\mathrm{H}_{2} \mathrm{O}_{2}$ pada saliva antara bayi normal $(10,92 \pm 2,53)$ dengan bayi dengan sepsis $(14,17 \pm 5,29)$ menunjukkan ada perbedaan yang bermakna $(p=0,041)$. Terlihat pula pada Tabel 3 menunjukkan bahwa ada perbedaan yang sangat bermakna $(p=0,000)$ mean kadar LTF pada saliva antara bayi normal $(37,13 \pm 4,11)$ dengan bayi dengan sepsis $(40,37 \pm 2,74)$. Secara keseluruhan pada bayi dengan risiko sepsis menunjukkan keadaan $\mathrm{MPO}, \mathrm{H}_{2} \mathrm{O}_{2}$, dan LTF yang lebih tinggi secara signifikan dibanding dengan kondisi normal.

Tabel 3. Perbandingan MPO, $\mathrm{H}_{2} \mathrm{O}_{2}$, dan LTF pada saliva

\begin{tabular}{cccc}
\hline \multirow{2}{*}{ Variabel } & Bayi normal & Bayi dengan sepsis & \multirow{2}{*}{$p$-value } \\
\cline { 2 - 3 } & Rearata \pm SD & Rerata \pm SD & \\
\hline MPO & $38,74 \pm 10,57$ & $75,23 \pm 13,18$ & 0,000 \\
$\mathrm{H}_{2} \mathrm{O}_{2}$ & $10,92 \pm 2,53$ & $14,17 \pm 5,29$ & 0,041 \\
LTF & $37,13 \pm 4,11$ & $40,37 \pm 2,74$ & 0,017 \\
\hline
\end{tabular}

Perbedaan $\mathrm{MPO}, \mathrm{H}_{2} \mathrm{O}_{2}$, dan LTF pada Darah Bayi dengan Risiko Sepsis dan Normal

Tampak pada Tabel 4 menunjukkan bahwa ada perbedaan yang sangat bermakna $(p=0,000)$ rerata kadar MPO pada darah antara bayi normal $(360,95 \pm 142,72)$ dengan bayi dengan sepsis $(623,52 \pm 97,55)$.

Tabel 4. Perbandingan MPO, $\mathrm{H}_{2} \mathrm{O}_{2}$, dan LTF pada darah

\begin{tabular}{cccc}
\hline \multirow{2}{*}{ Variabel } & Bayi normal & Bayi dengan sepsis & \multirow{2}{*}{$p$-value } \\
\cline { 2 - 3 } & Rerata \pm SD & Rerata \pm SD & \\
\hline MPO & $360,95 \pm 142,72$ & $623,52 \pm 97,55$ & 0,000 \\
$\mathrm{H}_{2} \mathrm{O}_{2}$ & $10,71 \pm 2,28$ & $13,17 \pm 2,71$ & 0,012 \\
LTF & $33,35 \pm 3,29$ & $35,57 \pm 2,09$ & 0,035 \\
\hline
\end{tabular}

Hal yang sama juga terjadi pada mean kadar $\mathrm{H}_{2} \mathrm{O}_{2}$ pada darah antara bayi normal $(10,71 \pm 2,28)$ dengan bayi dengan sepsis $(13,17 \pm 2,71)$ menunjukkan ada perbedaan yang bermakna $(p-=0,012)$. Terlihat pula pada Tabel 4 menunjukkan bahwa ada perbedaan yang sangat bermakna $(p=0,035)$ mean kadar LTF pada darah antara bayi normal $(33,35 \pm 3,29)$ dengan bayi dengan sepsis $(35,57 \pm 2,09)$. Hal ini menjelaskan bahwa pada darah pasien sepsis neonatal menunjukkan peningkatan kadar LTF dibandingkan pada pasien normal.

\section{Hasil Analisis Jalur pada Sampel Saliva}

Jumlah neutrofil (R2) berpengaruh langsung terhadap kadar TLR2 ditunjukkan dengan koefisien pengaruh sebesar 0,570. Nilai positif pada 0,570 dapat diartikan ada pengaruh hubungan yang positif atau seiring antara R2 terhadap TLR2. Demikian pula R2 berpengaruh langsung terhadap TLR4 ditunjukkan dengan koefisien pengaruh sebesar 0,934. Peningkatan neutrofil dalam penelitian ini

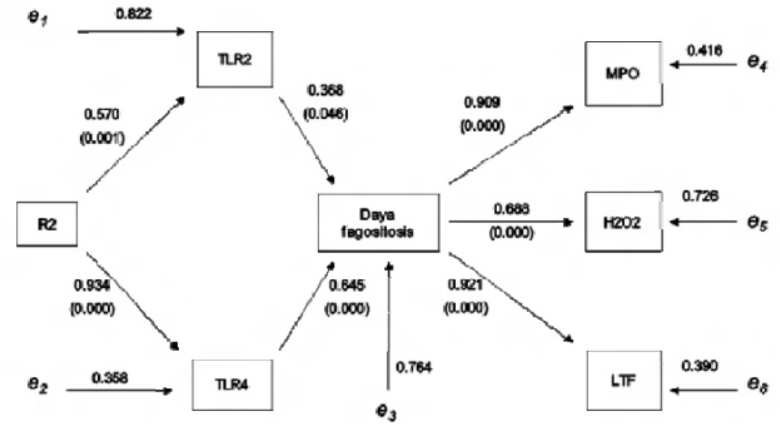

Gambar 3. Koefisien jalur kuantitas, kualitas fagositosis, neutrofil pada sampel saliva

akan meningkatkan TLR4 terhadap pasien sepsis neonatal, demikian pula sebaliknya. TLR2 berpengaruh langsung terhadap fagositosis sebesar 0,368 dan TLR4 berpengaruh langsung terhadap fagositosis sebesar 0,645. Nilai positif pada 0,368 dan 0,645 dapat diartikan ada pengaruh hubungan yang positif atau seiring antara TLR2 dan TLR4 terhadap fagositosis. Fagositosis berpengaruh langsung terhadap kadar MPO ditunjukkan dengan koefisien pengaruh sebesar 0,909. Nilai positif pada 0,909 dapat diartikan ada pengaruh hubungan yang positif atau seiring antara fagositosis terhadap MPO. Demikian pula fagositosis berpengaruh langsung terhadap $\mathrm{H}_{2} \mathrm{O}_{2}$ yang ditunjukkan dengan koefisien pengaruh sebesar 0,688. Nilai positif pada 0,688 dapat diartikan ada pengaruh hubungan yang positif atau seiring antara fagositosis terhadap $\mathrm{H}_{2} \mathrm{O}_{2}$. Fagositosis berpengaruh langsung terhadap LTF yang ditunjukkan dengan koefisien pengaruh sebesar 0,921. Nilai positif pada 0,921 dapat diartikan ada pengaruh hubungan yang positif atau seiring antara fagositosis terhadap LTF. Validasi model pada uji korelasi antar variabel sangat tinggi, karena prosentasi validitas model ketiganya mendekati nilai $100 \%$, yaitu MPO $(99,1$ $\%), \mathrm{H}_{2} \mathrm{O}_{2}(97,3 \%), \operatorname{LTF}(99,2 \%)$.

\section{Hasil Analisis Jalur pada Sampel Darah}

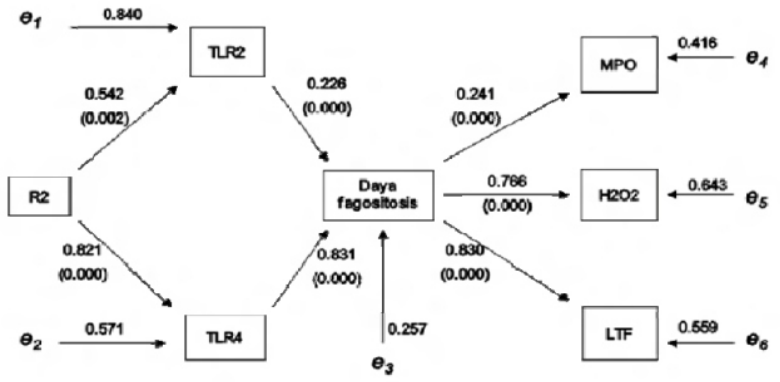

Gambar 4. Koefisien jalur kuantitas,kualitas fagositosis, neutrofil pada darah

Jumlah neutrofil pada darah berpengaruh langsung terhadap kadar TLR2 ditunjukkan dengan koefisien pengaruh sebesar 0,542. Nilai positif pada 0,542 dapat diartikan ada pengaruh hubungan yang positif atau seiring antara R2 terhadap TLR2. Demikian pula R2 berpengaruh langsung terhadap TLR4 ditunjukkan dengan koefisien pengaruh sebesar 0,821 . Nilai positif pada 0,821 dapat diartikan ada pengaruh hubungan yang positif atau seiring 
antara R2 terhadap TLR4. TLR2 berpengaruh langsung terhadap fagositosis sebesar 0,226 dan TLR4 berpengaruh langsung terhadap fagositosis sebesar 0,831 . Nilai positif pada 0,831 dapat diartikan ada pengaruh hubungan yang positif atau seiring antara TLR2 dan TLR4 terhadap fagositosis. Fagositosis berpengaruh langsung terhadap kadar MPO ditunjukkan dengan koefisien pengaruh sebesar 0,241. Nilai positif pada 0,241 dapat diartikan ada pengaruh hubungan yang positif atau seiring antara fagositosis terhadap MPO. Demikian pula fagositosis berpengaruh langsung terhadap $\mathrm{H}_{2} \mathrm{O}_{2}$ ditunjukkan dengan koefisien pengaruh sebesar 0,766 . Nilai positif pada 0,766 dapat diartikan ada pengaruh hubungan yang positif atau seiring antara fagositosis terhadap $\mathrm{H}_{2} \mathrm{O}_{2}$. Selanjutnya fagositosis berpengaruh langsung terhadap LTF ditunjukkan dengan koefisien pengaruh sebesar 0,830. Nilai positif pada 0,830 dapat diartikan ada pengaruh hubungan yang positif atau seiring antara fagositosis terhadap LTF. Validasi model pada uji korelasi ketiga model mendekati nilai $100 \%$, yaitu MPO $(99,8 \%), \mathrm{H}_{2} \mathrm{O}_{2}(99,4 \%)$, LTF (99,5 \%). Hal ini menunjukkan bahwa tingkat kesalahan dalam penelitian ini sangat kecil pada model konseptual yang telah diajukan.

\section{PEMBAHASAN}

Neutrofil merupakan sel fagosit lini pertama dalam sistem imunitas natural, dan pada keadaan normal jumlah neutrofil bayi baru lahir lebih banyak daripada anak maupun orang dewasa (7). Neutrofil menggunakan tiga strategi utama untuk melawan dan membunuh mikroba patogen yaitu fagositosis, degranulasi dan pembentukan Neutrophyl Extracelluler Trap (NET). Pada proses fagositois, neutrofil menelan mikroba ke dalam fagosom, sedangkan pada proses degranulasi, neutrofil melepaskan granula protease, yang antara lain dapat menyebabkan kerusakan pada sel penjamu. Penggabungan granula protease ke NET membatasi difusi mereka dan potensi kerusakan sel penjamu dapat dikurangi, meningkatkan konsentrasi efektif lokal, dan menjebak serta membunuh bakteri (8).

Bhandari et al. (2008) melaporkan bahwa kombinasi indeks CD64 dengan jumlah neutrofil absolut mempunyai nilai negative predictive value dan sensitivitas yang tinggi, yaitu $93 \%$ dan $95 \%$ (9). Belum banyak dilaporkan penelitian tentang ekspresi TLR2, TLR4 pada bayi baru lahir. Viemann et al. (2005) yang melakukan penelitian ekspresi TLR2 dan TLR4 pada granulosit dan monosit dari vena perifer 20 orang dewasa sehat, dan dari vena tali pusat 85 bayi baru lahir ( 32 bayi sepsis dan 53 bayi sehat), melaporkan bahwa ekspresi TLR2 pada bayi sehat sedikit lebih rendah dibandingkan orang dewasa sehat, sedangkan ekspresi TLR4 pada kedua kelompok ini tidak ada perbedaan yang bermakna. Terdapat upregulasi TLR2 yang nyata pada kelompok bayi sepsis dibandingkan dengan bayi sehat, sesuai dengan hasil pemeriksaan CRP, IL-6 dan IL-8. Sedangkan ekspresi TLR4 pada bayi sepsis dibandingkan dengan bayi sehat, tidak terdapat perbedaan yang bermakna (10). Hal ini sesuai dengan penelitian ini, yang menunjukkan ekspresi TLR2 lebih tinggi secara bermakna pada bayi bayi dengan sepsis dibandingkan dengan bayi normal. Berbeda dengan penelitian lain, pada bayi-bayi yang terinfeksi bronkiolitis RSV (respiratory syncytial virus) terdapat penurunan secara bermakna ekspresi TLR4 neutrofil (11).
Djojohusodo (2012) melaporkan bahwa ekspresi TLR2 dan TLR 4 menurun pada bayi berat lahir rendah (preterm murni) yang mengalami sepsis dibandingkan dengan dengan bayi-bayi aterm sehat (12).

Telah terbukti bahwa saliva mempunyai banyak manfaat $(13,14)$, antara lain mengandung senyawa antimikrobial, sebagai biomarker penyakit-penyakit infeksi $(15,16)$, keganasan $(17,18)$, serta sebagai sarana monitor keberhasilan transplantasi sumsum tulang (19). Neutrofil berperan aktif dalam respon akut terhadap mikroba patogen di berbagai jaringan, dengan influks menuju kavitas oral terjadi kapan saja. Pada penelitian ini juga didapatkan peningkatan ekspresi TLR2 secara bermakna pada saliva dan darah bayi dengan sepsis dibandingkan dengan bayi normal. Peningkatan ekspresi TLR2 pada penelitian ini sesuai dengan penelitian William et al. (2003) pada binatang coba, dan Vieman et al. (2005) pada bayi dengan sepsis neonatal, ekspresi TLR2 yang meningkat dapat digunakan sebagai petanda awal adanya sepsis $(10,20,21)$. Didapatkan hasil yang sama pada darah bayi dengan sepsis, adanya peningkatan mean jumlah neutrofil yang bermakna dibandingkan dengan darah kelompok control. Apabila dibandingkan antara saliva dan darah bayi dengan sepsis, ternyata mean jumlah neutrofil yang meningkat bermakna pada saliva lebih tinggi dibandingkan dengan darah. Hal ini membuktikan bahwa aktivasi neutrofil sudah dimulai sejak awal di saliva.

Pada analisis tentang daya fagositosis yang dipapar bakteri dengan rentang waktu yang berbeda (30 menit dan 60 menit) diperoleh hasil bahwa tingkat fagositosis neutrofil dalam rentang waktu 60 menit lebih tinggi dibandingkan dengan 30 menit. Hal ini menunjukkan bahwa semakin lama neutrofil dipapar dengan suatu jenis bakteri maka kemampuannya dalam memfagosit bakteri tersebut semakin meningkat dan neutrofil menjadi semakin aktif. Hasil ini sesuai dengan hasil pengukuran sebelumnya bahwa terjadi peningkatan jumlah neutrofil dan ekspresi TLR2 dan TLR4 pada bayi dengan sepsis. Pengukuran terhadap kualitas neutrofil pada sampel darah dan saliva ditunjukkan dengan cara mengukur produksi $\mathrm{MPO}, \mathrm{H}_{2} \mathrm{O}_{2}$, dan LTF. Bayi risiko sepsis kasus menunjukkan tingkat produksi MPO, $\mathrm{H}_{2} \mathrm{O}_{2}$, dan LTF yang lebih tinggi dibandingkan dengan bayi normal. Hal ini sesuai dengan pengukuran sebelumnya, bahwa terjadinya peningkatan jumlah neutrofil dan daya fagositosis neutrofil akan mengaktifkan transduksi sinyal selanjutnya sehingga meningkatkan produksi MPO, $\mathrm{H}_{2} \mathrm{O}_{2}$, dan LTF yang digunakan untuk membunuh bakteri patogen.

Bukti yang menunjukkan adanya radikal hidroksil terdapat dalam neutrofil masih kontroversial. Hal ini disebabkan oleh sulitnya penggunaan alat ukur dengan pendekatan produk sekunder, atau dengan inhibitor yang mungkin spesifitasnya rendah serta adanya keterlibatan senyawa oksigen reaktif lain seperti superoksid atau $\mathrm{HOCl}$ dalam reaksi tersebut. Sebagian besar oksigen yang dikonsumsi akan dirubah sebagai hidrogen peroksida, sehingga berlangsung dismutasi dari oksigen menjadi radikal superoksida yang selanjutnya diubah menjadi hidrogen peroksida. Meskipun demikian, hidrogen peroksida dapat membunuh bakteri apabila tersedia dalam konsentrasi tinggi dan radikal superoksida tidak dapat membunuh bakteri secara langsung. Radikal hidroksil $(\mathrm{OH})$ adalah oksigen radikal yang paling reaktif dan sangat sitotoksik. Waktu paruh radikal hidroksil sangat pendek sekitar $10^{-9}$ 
detik dan mampu berdifusi kurang dari $2 \mathrm{~nm}$ dari tempat formasinya. Hidrogen peroksida $\left(\mathrm{H}_{2} \mathrm{O}_{2}\right)$ dan radikal superoksida $\left(\mathrm{O}_{2}\right)$ bersifat kurang reaktif dan mempunyai waktu paruh lebih lama dibandingkan radikal hidroksil. Hanya hidrogen peroksida yang mampu berdifusi menembus membran dan menuju sel (22). Myeloperoxidase adalah enzim yang mengandung heme disekrisi oleh sel-sel fagosit setelah adanya aktivasi dari sistem respiratoty burst. Myeloperoxidase biasanya digunakan sebagai marker akumulasi neutrofil dalam jaringan dan merupakan marker dari aktivitas neutrofil ketika dilakukan pengukuran di plasma (23). Myeloperoxidase merupakan heme peroksidase klasik yang menggunakan hidrogen peroksida untuk mengoksidasi berbagai senyawa aromatik $(\mathrm{RH})$ melalui mekanisme satu elektron membentuk radikal aromatik (R). Hal ini sangat khas sehingga siap untuk mengoksidasi ion klorida menjadi senyawa oksigen reaktif nonradikal kuat yaitu $\mathrm{HOCL}$. $\mathrm{HOCl}$ adalah senyawa oksigen reaktif yang diproduksi oleh neutrofil serta bersifat sangat bakterisidal.

Berbagai spesies bakteri akan terbunuh oleh sistem myeloperoksidase dan hidrogen peroksida dan klorida. Target pada bakteri yang paling sensitif meliputi protein besi-sulfur, protein transport membran, sistem pembentuk adenosin trifosfat (ATP), dan lokasi untuk replikasi DNA. Kloramin akan dibentuk secara tidak langsung akibat reaksi antara $\mathrm{HOCl}$ dengan amina yang juga bersifat bakterisidal (24). LTF mampu menghambat pertumbuhan bakteri gram positif dan bakteri gram negatif. LTF dapat menghambat metabolisme melalui sintesis bobot molekul yang rendah dengan proses chelation (siderophores), atau dengan produksi reseptor

\section{DAFTAR PUSTAKA}

1. Haque K. Management of Bacterial Infection on the Newborn. Journal Arab Neonatal Forum. 2006; 3: 4145.

2. Bizzaro JM, Raskind C, Baltimore RS, and Gallagher PG. Seventy-Five Years of Sepsis At Yale: 1928-2003. Pediatrics. 2005; 116 (3): 595-602.

3. Quinn MT and Gauss KA. Structure and Regulation of the Neutrophil Respiratory Burst Oxidase: Comparison with Nonphagocyte Oxidases. Journal of Leukocyte Biology. 2004; 76(4): 760-781.

4. Ashby MT. Inorganic Chemistry of Defensive Peroxidase in the Human Oral Cavity. Journal of Dental Research. 2008; 87(10): 900-914.

5. Gasparoto TH, Vieira NA, Porto VC, Campanelli AP, and Lara VS. Ageing Exacerbates Damage of Systemic and Salivary Neutrophils from Patients Presenting Candida-Related Denture Stomatitis. Immunity and Ageing. 2009; 6(3): 1-12.

6. Aminullah A. Sepsis pada Bayi Baru Lahir - Masalah dan Penatalaksanaannya. Proceeding Simposium Nasional I Ikatan Dokter Anak Indonesia Cabang Kalimantan Selatan. Banjarmasin, 2005; hal. 68-86.

7. Urlichs F and Speer CP. Neutrophil Function in Preterm and Term Infants. NeoReviews. 2004; 5(10): 417-430. spesifik LTF yang dapat memfasilitasi pelepasan zat besi dari protein (25). Peran utama LTF dalam mekanisme pertahanan penjamu adalah sebagai bakteriostatik yang akan menghambat proliferasi bakteri melalui kemampuan sekuestrasi besi. Selain bakteriostatik, LTF juga berfungsi bakterisidal, efek bakterisidal ini berasal dari aktivasi laktoferisin B sebagai molekul peptida derivat proteolitik dari regio $\mathrm{N}$ terminal LTF. Efek bakterisidal ini disebabkan oleh kemampuan LTF merusak permukaan luar membran bakteri yang berakibat perubahan permiabelitas membran. Kerusakan membran tersebut akibat inkorporasi LTF dengan membran yang akan menghambat lipopolisakarida melalui proses yang dimodulasi oleh kation $\left(\mathrm{Ca}^{2+}, \mathrm{Mg}^{2+}\right.$, atau $\left.\mathrm{Fe}^{2+}\right)(26)$.

Perbandingan jumlah neutrofil, ekspresi TLR2, TLR4 bayi dengan sepsis kasus lebih tinggi dibandingkan dengan bayi normal baik pada sampel darah dan saliva. Perbandingan jumlah neutrofil dan daya fagositosis lebih tinggi bayi dengan sepsis dibandingkan dengan bayi normal. Tingkat fagositosis neutrofil dalam rentang waktu 60 menit lebih tinggi dibandingkan dengan 30 menit. Bayi dengan sepsis menunjukkan tingkat produksi $\mathrm{MPO}, \mathrm{H}_{2} \mathrm{O}_{2}$, dan LTF yang lebih tinggi dibandingkan dengan bayi normal. Dengan menggunakan analisa jalur, penggunaan variabel dependen yang lain diharapkan dapat meningkatkan nilai validitas model. Perlu penelitian lebih lanjut untuk penggunaan saliva sebagai sarana pemeriksaan biomarker sepsis neonatal awitan dini. Pemahaman yang lebih baik tentang patobiologi TLRs khususnya pada saliva akan membuka cakrawala yang luas tentang deteksi dini dan terapi yang adekuat pada sepsis neonatorum yang sangat bermanfaat dalam menurunkan morbiditas maupun mortalitas sepsis neonatal menuju percepatan pencapaian target MDGs4

8. Papayannopoulos $\mathrm{V}$ and Zychlinsky A. NETs: A New Strategy for Using Old Weapons. Trends in Immunology. 2009; 30 (11): 513-521.

9. Bhandari V, Wang C, Rinder C, and Rinder $\mathrm{H}$. Hematologic Profile of Sepsis in Neonates: Neutrophil CD64 as a Diagnostic Marker. Pediatrics. 2008; 121 (1): 129-134.

10. Viemann D, Dubbel G, Schleifenbaum S, Harms E, Sorg C, and Roth J. Expression of Toll-Like Receptor in Neonatal Sepsis. Pediatric Research. 2005; 58(4): 654659.

11. Halfhide CP, Brearey SP, Flanagan BF, et al. Neutrophil TLR4 Expression is Reduced in the Airways of Infants with Severe Bronchiolitis. Thorax. 2009; 64(9): 798805.

12. Djojohusodo D. Ekspresi Toll Like Receptor 2,4 Sebagai Petanda Dini Infeksi Perinatal Pada Bayi Berat Lahir Rendah Sesuai Masa Kehamilan. [Disertasi]. Universitas Brawijaya, Malang. 2012.

13. Samaranayake LP. Is Saliva the Magic Diagnostic Fluid We were Waiting for? The Saudi Dental Journal. 2008; 20(3).

14. Lima DP, Diniz DG, Sumida DH, Moimaz SA, and Okamoto AC. Saliva: Reflection of the Body. International Journal of Infectious Desease. 2010; 14(3): e184-e188. 
15. Kumar PS, Kumar S, Savadi RC, and John J. Nanodentistry: A Paradigm Shift-From Fiction to Reality. Journal of Indian Prosthodontic Society. 2011; 11(1): 1-6.

16. Ogawa K, Furukawa S, Fujita S, et al. Inhibition of Streptococcus Mutans Biofilm Formation by Streptococcus Salivarius Frua. Applied and Environmental Microbiology. 2011; 77(5): 15721580.

17. Wong DT. Salivary Diagnostiks Powered by Nanotechnologies, Proteomics and Genomics. The Journal of the American Dental Association. 2006; 137: 313-321.

18. Markopoulos AK, Michailidou EZ, and Tzimagiorgis G. Salivary Markers for Oral Cancer Detection. The Open Dentistry Journal. 2010; 4: 172-178.

19. Pink R, Simek J, Vondrokova J, et al. Saliva as a Diagnostic Medium. Biomedical Papers of the Medical Faculty of the University Palacky, Olomouc, Czech Republic. 2009; 153(2): 103-110.
20. William DL, Ha T, Li C, et al. Modulation of Tissue TolLike Receptor 2 And 4 during the Early Phases of Polymicrobial Sepsis Correlates with Mortality. Critical Care Medicine. 2003; 31(6): 1808-1818.

21. Tsujimoto H, Ono S, Efron PA, Scumpia PO, Moldawer $\mathrm{LL}$, and Mochizuki H. Role of Toll-Like Receptors in the Development of Sepsis. Shock. 2008; 29(3): 315-321.

22. Vrba J and Modriansky M. Respiratory Burst Of Kupffer Cells: Target for Liver Injury Treatment. Biomedical Papers. 2002; 146 (2): 15-20.

23. Toumi H, F'guyer S, and Best TM. The Role of Neutrophils in Injury and Repair Following Muscle Stretch. Journal of Anatomy 2006; 208: 459-470.

24. Klebanoff SJ. Myeloperoxidase: Friend or Foe. Journal of Leukocyte Biology. 2005; 77(5): 598-625.

25. Brock JH. The Physiology of Lactoferrin. Biochemistry and Cell Biology. 2002; 80(1): 1-6.

26. Kruzel ML, Actor JK, Boldogh I, and Zimecki M. Lactoferrin in Health and Disease. Postępy Higieny i Medycyny Doświadczalnej. 2007; 61: 261-267. 